\title{
In search of opportunities? The barriers to more efficient internal labor mobility in Ukraine
}

\author{
Johannes Koettl ${ }^{1,3^{*}}$, Olga Kupets ${ }^{1,2}$, Anna Olefir ${ }^{1,3}$ and Indhira Santos ${ }^{1}$
}

\author{
* Correspondence: \\ jkoettl@worldbank.org \\ 'World Bank, 1818 H Street NW, \\ Washington, DC 20433, USA \\ ${ }^{3}$ World Bank Country Office in \\ Moldova, 20/1 Pushkin Street, \\ MD-2012 Chisinau, Republic of \\ Moldova \\ Full list of author information is \\ available at the end of the article
}

\begin{abstract}
Ukraine's economy lacks dynamism, and this is both the cause and the effect of people not moving across the regions. The rate at which Ukrainians move from one region to another within the country is only half of what would be expected in comparison with other countries. This paper examines the barriers that prevent workers from moving within Ukraine, using information from focus group discussions and expert surveys. It also offers recommendations for creating greater labor mobility in Ukraine through addressing institutional bottlenecks and defines five key areas for improvement, including the population registry system, housing and credit markets, vocational education and training systems, labor market institutions, and the social welfare system.
\end{abstract}

JEL Classification: J61; J68; P25

Keywords: Internal labor mobility; Housing market; Barriers to migration; Transition economies

\section{Introduction}

The transition to a market economy in many Eastern European countries has been typically accompanied by a significant shift from widely-dispersed industries to a concentration of capital and production in a few areas. Labor has largely mirrored the movement of capital and production, leading to large economic gains.

In Ukraine, however, labor is not flowing as smoothly to the areas where production and capital are concentrated. Ukrainians do not move often, and when they do move, they don't necessarily go to areas with more jobs and higher wages. Internal mobility is about half of what is expected when comparing Ukraine with other countries, despite large economic differentials. Hence, relatively few people are taking advantage of economic opportunities in other areas, and the challenge is to explain why they fail to seize these opportunities.

A 2004 study of the determinants of inter-regional migration in Ukraine found that that the drivers of internal migration in Ukraine have changed significantly over time, with labor market conditions becoming less and less relevant to people's decision to move (Martynenko 2004). Kupets (2012, 2014a, b) examined why migration flows between some Ukrainian regions were almost non-existent, while between other regions, which are typically very similar in terms of social and economic development, there were substantial flows in both directions, concluding that the geographic distance provides a serious obstacle to residential migration within Ukraine. In particular,

(c) 2014 Koettl et al.; licensee Springer. This is an Open Access article distributed under the terms of the Creative Commons Attribution License (http://creativecommons.org/licenses/by/4.0), which permits unrestricted use, distribution, and reproduction in any medium, provided the original work is properly credited. 
Kupets (2014b) finds that the estimated distance elasticity of migration increased from minus 0.91-0.92 in 2008 to minus 0.96-1 in 2012. Significant effects of the distance between the regions' major cities and of a common land border between regions (used as a proxy for cultural, religious and political proximity in addition to geographic proximity) show that direct and indirect migration costs, including the costs of moving to dissimilar regions in terms of culture, religion, and political attitudes (but not in terms of the language), have deterring effects on residential inter-regional migration in Ukraine. Besides, these empirical studies show that Ukrainians seem to only partially respond to the unemployment and wage differentials, but importantly also to inter-regional differences in local per capita public expenditures on education, health care and social assistance (Kupets 2014a), the number of doctors, crime rate and air pollution (Kupets 2014b). However, the effects of economic, social and environmental variables are not always significant and in the expected direction. Finally, in a study of temporary labor migration and commuting of the employed population, based on labor force survey data, it has been found that although intra-regional flows dominate over inter-regional and international flows in all regions, there were six regions in which workers were more likely to go for temporary employment abroad rather than to some other region within Ukraine (Kupets 2012). This suggests that, in view of more attractive employment opportunities and much higher expected returns, cross-border external migration is often used as a substitute for long-distance migration within Ukraine.

The main objective of this paper is to explore the barriers to internal migration in Ukraine using qualitative information from expert surveys and focus group discussions. To provide insights into the attitudes of migrant workers, the unemployed and employed towards internal migration, as well as their motivations to move and the most salient barriers to internal mobility, nineteen focus group discussions were conducted by the Kiev International Institute of Sociology (KIIS) between March and April 2012. The findings of these focus group discussions were complemented by a survey of nineteen experts, including representatives of trade unions and employers' organizations, and researchers of labor market and migration issues, and by consultations with policymakers, social partners and representatives of the private sector.

The major barriers to internal mobility are found to be mainly institutional. Internal labor mobility is low and inefficient because of weaknesses in five main areas: (i) administrative procedures, reflected in a population registry system that binds people to their place of residence and increases the costs of internal migration; (ii) underdeveloped housing and credit markets that make housing in leading regions unaffordable to potential migrants, particularly the poor; (iii) insufficient human capital, as people in lagging regions often lack the necessary skills to access better economic opportunities in high productivity, modern sectors in the leading regions; (iv) weak formal labor market institutions that sustain labor market and wage rigidities, encourage informality and do not provide workers with enough reliable information about job openings and labor market conditions; and (v) social benefits that are tied to the officially registered place of residence and therefore often discourage relocation to another area. Individual sociopsychological factors such as strong ties to families, friends and local community and overall reluctance of Ukrainians to relocate, even for a better job and living standards, are also important constraints to mobility frequently mentioned by experts and focus group informants. 
In the face of weak formal institutions that are supposed to help people connect to economic opportunities, Ukrainians often circumvent these institutions and have to rely on alternative solutions, which are mostly unregulated, do not provide formal protection and entail high levels of uncertainty. Over-reliance on informal social networks, employment, and housing together with corruption are the major examples of these solutions. Although informal networks and practices help many people to solve their social and economic problems, they are suboptimal as they often lead to too costly and risky outcomes.

Hence, the main policy implication is the need to address the existing institutional bottlenecks that affect internal mobility in order to allow people, especially the poor, to move more freely from lagging, job-scarce regions to leading regions with better employment and income opportunities. Given the critical demographic situation in Ukraine, with a population that is rapidly shrinking and aging, the issues of removing existing barriers to internal mobility need to be put high on the present reform agenda because an older population is much less likely to migrate for economic reasons.

Apart from aging, globalization and international competition make more mobility all the more necessary by pressing Ukraine to push ahead with the modernization of its economy. This will require further agglomeration of capital and labor, a process that in Ukraine has so far been slower than in peer countries.

The remainder of the paper is organized as follows. Section 2 offers a brief literature review of how a mobile workforce can benefit the economy and why it is important for Ukraine. Section 3 provides some background information on the magnitude and patterns of internal migration in Ukraine. Section 4 examines the main barriers to migration of Ukrainians within the country. Section 5 offers policy recommendations, and Section 6 concludes.

\section{Potential benefits of internal migration: literature review}

The concentration of people, capital and production was fundamental in the development of industrialized countries in North America, Western Europe, and Northeast Asia. Because economic prosperity did not happen everywhere at the same time in those countries, people had to relocate to find economic opportunities and productive jobs. This concentration in turn stimulated further growth and rising living standards.

A large volume of theoretical and empirical work from developed and developing countries, summarized in Chapter 5 of the 2009 World Development Report (World Bank 2009a), suggests that voluntary internal migration for economic reasons does not only increase the earnings of migrants but also contributes to aggregate economic growth by improving the distribution of labor, clustering skills and talents, and driving agglomeration spillovers. Studies on migration, development and poverty reduction in Asian countries such as Bangladesh, China, India, Pakistan and Vietnam (International Organization for Migration 2005) also show that, if managed properly, internal migration, particularly from rural to urban areas, plays an important role in poverty reduction in sending areas as the flow of money, goods and services between rural and urban areas increases demand for local agricultural output, stimulates the non-farm economy and absorbs surplus labor. For example, IOM 2005 estimated that labor migration from rural to urban areas in China contributed 16 percent of total GDP growth in the period 
between 1978 and 1997 (International Organization for Migration 2005, p.70). Similarly, Lall et al. (2006) estimated that 30 percent of India's urban economic growth is accounted for by the movement of more than 20 million Indians from rural to urban areas in the 1990s.

There is also evidence that Canada's economic growth in the 1990s and early 2000s had significantly benefitted from labor migration from the low-productive eastern provinces to highly-productive western provinces (Sharpe et al. 2007). This study asserts that interprovincial migration was responsible for 1.3 percent of real trend GDP growth in Canada over the 1987-2006 period and 2.8 percent of the actual real GDP growth in 2006. At the same time, the authors point out that reallocation of labor between provinces does not produce productivity growth in itself, but it ensures that potential productivity gains resulted from increased human capital, technological advancement, and capital investment are further exploited.

Internal migration also offers societies an opportunity for the convergence in living standards among individuals and regions, while reducing overall macroeconomic volatility and contributing to the absorption of shocks, as suggested by neoclassical economic theory. Proponents of the New Economic Geography, on the other hand, argue that selective migration for economic reasons can lead to a backwash effect and huge divergence rather than convergence between "lucky" and "unlucky" regions (Moretti 2012; Myrdal 1963). The empirical evidence also provides quite mixed results. For example, the 2009 World Development report (World Bank 2009a) argues that recent empirical studies show the positive impact of migration on income convergence in developed and developing economies, often after an initial divergence in low and middle-income countries. At the same time, Vakulenko (2014) concludes that various studies using a similar $\beta$-convergence model but different sets of control variables and estimation methods find positive, negative and insignificant relationships between migration and convergence. In the same paper, findings from Russia suggest that there are positive effects of migration on income and wages in sending regions, but the impact is quite small, probably because the regional income convergence in Russia mainly happens through capital mobility and the subsequent development of financial and real estate markets rather than through labor mobility.

It is important to note that there are also potential costs associated with high internal mobility. In fast-growing urban areas in developing countries, traffic congestion and overcrowding, lack of sufficient housing, environmental degradation, increased crime rate, growing inequalities in access to jobs, housing, education, safety, cultural and social amenities are often a problem (International Organization for Migration 2005). At the individual level, both internal and cross-border migration is also associated with many risks and costs that reduce the benefits, especially for poor families. Among the many hardships are: debt bondage as migrants borrow money to migrate; dangerous and difficult working conditions; living in the open or in very poor accommodation with inadequate water and sanitation; crime and personal safety issues; lack of information about rights, entitlements and the applicable law in general; lack of access to health services, education (for migrant's children) and other government services; and discrimination (International Organization for Migration 2008 Chapter 7. Internal migration. In: World migration report 2008). But appropriate urban planning and social policies can help mitigate some of the potential negative effects of internal labor mobility. 
To sum up, there are important economic gains that can be realized from intensive and efficient internal migration, both in terms of economic growth but also in terms of living standards of individuals. The potential for mobility of workers to contribute to higher productivity, economic growth and living standards is especially critical for a transition country like Ukraine, whose economy is going through a fundamental process of structural transformation. Yet, so far, the pace of restructuring and modernization has been slow: Among transition economies, Ukraine had one of the least agglomerated economy and population in 1990, but it experienced almost no agglomeration since then. Despite a slight convergence in regional unemployment rates and wages over the last decade, there are substantial regional disparities, particularly in regional output per worker (see Figure 1).

According to the studies on poverty in Ukraine (Brück et al. 2010; United Nations Development Programme 2008; World Bank 2005), the country has not taken full advantage of internal migration of workers and their families for bringing down these regional imbalances. We return to this issue of what keeps Ukrainians from taking advantage of internal migration after a brief discussion on past patterns of migration within the country.

\section{Magnitude and patterns of internal migration in Ukraine}

The primary source of data on migration flows in Ukraine is administrative data on inmigration (inflows), out-migration (outflows) and net migration (inflows minus outflows) based on population registration of the place of residence (see the details in Section 4.1). This administrative data refers to those changes of residence that are registered with the State Migration Service and published by the State Statistics Service of Ukraine. Therefore, these data refer mainly to residential mobility, but many moves of workers and their families might go unregistered. This means that administrative internal migration data is likely to underestimate actual migration, as corroborated by the survey of labor market experts conducted for this report. However, we complement this source of data with additional microeconomic sources based on household surveys to get a more complete picture of migration patterns.

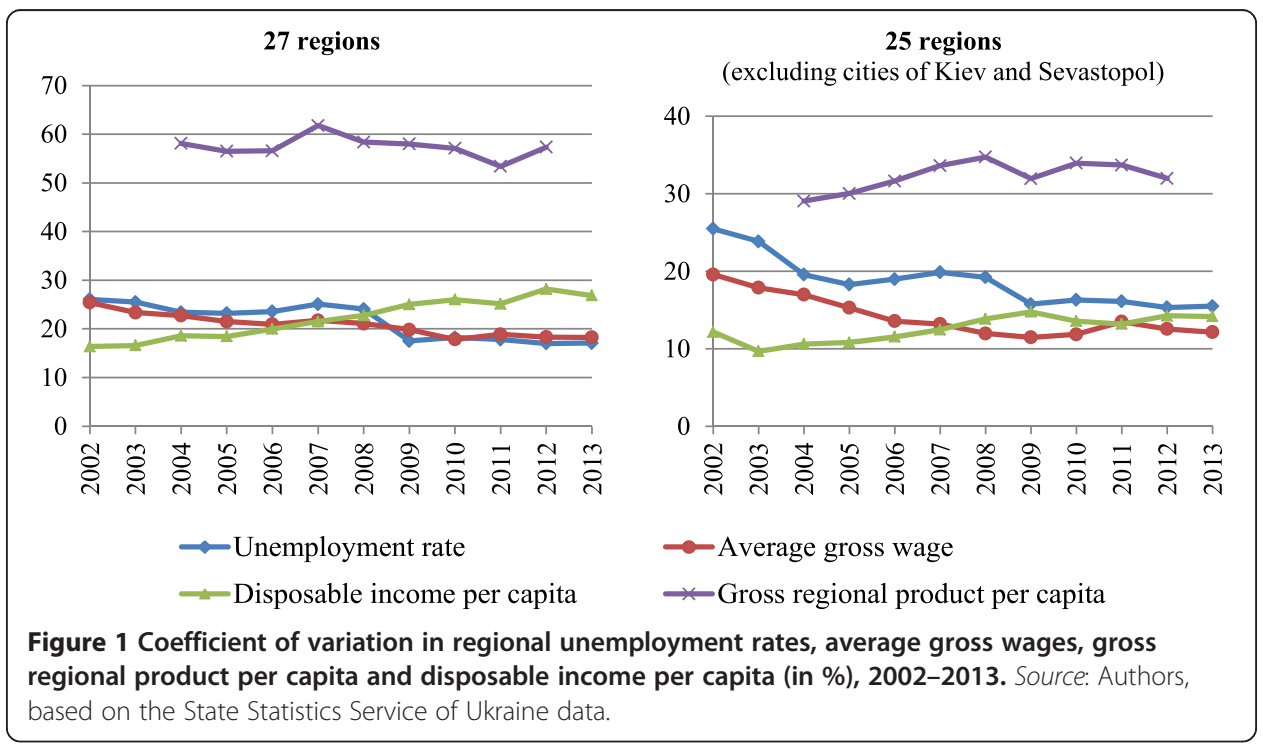


Official statistics indicate that about 622,000 people changed residency within Ukraine in 2013, which constitutes about 1.37 percent of the total population ${ }^{1}$. Despite some increase in 2010, the gross migration rate is not yet back to its pre-crisis levels (Figure 2). Moves from one region ${ }^{2}$ to another (inter-regional migration) represent around 42 percent of total registered internal migration while moves within the same administrative region (intra-regional migration) make up 58 percent.

The highest propensity to migrate is observed among youth aged 15 to 19, followed by the 20 to 24-year-olds, who move from their home places mainly to pursue studies after secondary school. Females and urban young people under 30 years have a higher propensity to migrate than their male and rural counterparts. On the other hand, men and the rural population appear to have a higher propensity of changing their official place of residence in older age when internal migration is more likely to be motivated by labor market reasons rather than by education or marriage. Overall, urban areas gain population through internal migration from both intra- and inter-regional migration. But these net gains have significantly reduced over the last years from about 53,000 people in 2005 to only about 14,000 people in 2013.

An analysis of inter-regional migration flows reveals that in most regions outmigration exceeded in-migration, resulting in negative net migration rates. The regions with the biggest net losses relative to its population were Kirovohrad, Kherson and Luhansk oblasts. There are some regions though that had consistent population gains through internal migration. These are Sevastopol City, Kiev oblast, Kiev City, Odesa, Chernivtsi and Kharkiv oblasts, and the Autonomous Republic of Crimea ${ }^{3}$. These migrant-attracting regions are located in different geographic parts of Ukraine and are not concentrated in certain areas, for example in the industrially developed East.

The rates of internal migration are low in Ukraine when compared to other countries. Using official statistics on internal migration and controlling for the average size of regions, we estimated that actual internal migration rates in Ukraine are about half of what we would expect when compared to other countries ${ }^{4}$. An alternative source of data for international comparison is the joint EBRD/World Bank "Life-in-Transition" survey, a large micro-data set that uses the same questionnaire and methodology across all countries of Eastern Europe and Central Asia and some Western European countries. According to this data, in Ukraine, 0.5 percent of the population moved within

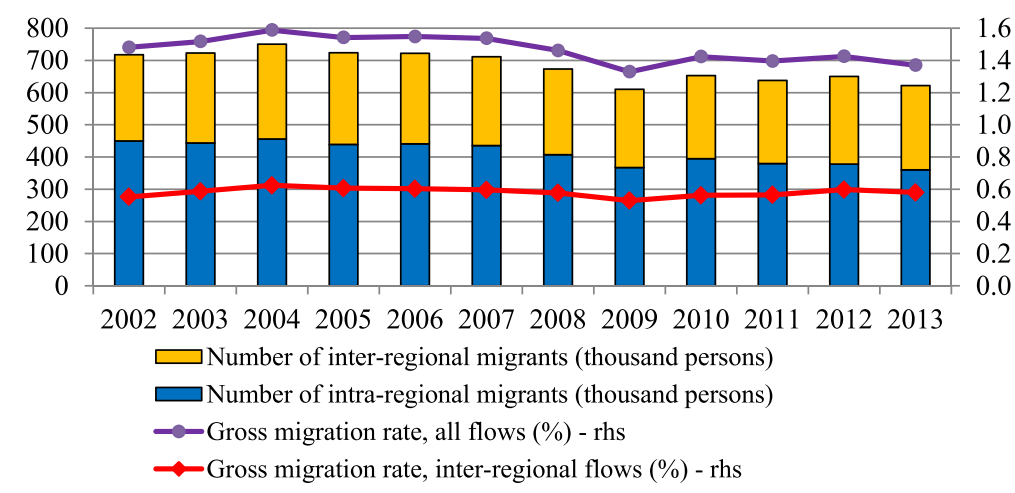

Figure 2 Indicators of internal migration in Ukraine, 2002-2013. Source: Authors, based on the State Statistics Service of Ukraine data. 
the year preceding the survey in 2010, and 4.5 percent moved within the last five years (Figure 3). Although data in this survey do not distinguish between external and internal migrations, Ukraine's migration rates are clearly at the lower end of the distribution when comparing across countries. Only 11 countries displayed lower migration rates, while 21 countries displayed higher rates than Ukraine.

Not only are Ukrainians not very mobile, it seems that also intentions to migrate are low when compared to other countries. According to Life-in-Transition data, 2 percent of Ukrainians said they planned to move abroad in the near future, and about 0.9 percent said they intended to move to other parts of Ukraine. Only three countries had a workforce that was less inclined to migrate internally, while 29 countries displayed higher rates.

Synovate, a global market research company (integrated into Ipsos in 2012), conducted a survey of labor mobility in Bulgaria, Russia, Serbia and Ukraine (Synovate 2010). The results of the survey confirmed the finding from the Life-in-Transition survey, namely low desire to relocate both in Russia and Ukraine. Specifically, if offered a 50 percent increase in salary, around 80 percent of respondents in Russia and Ukraine would still refuse to relocate. In Bulgaria and Serbia, only 50 percent would refuse.

In an environment of low residential labor mobility, commuting can be a substitute for labor and residential migration in facilitating transitions out of joblessness and smoothing regional disparities. This is precisely the case in Ukraine. According to the labor force survey, the total number of commuters was above 2.6 million employed people in 2010, or 13.2 percent of the employed population in Ukraine (Table 1). But only a small share of workers travel across regions. Inter-regional commuting rate (1.6 percent in 2010) is low in Ukraine when compared to the old EU member states, although it is comparable to those observed in Bulgaria, Poland or Romania (Paci et al. 2007).

Our findings regarding low internal migration in Ukraine, which is based on different data sources, is also consistent with local perceptions. In a survey of labor market experts conducted for this study, 12 out of 19 respondents said that internal mobility rates in Ukraine are low when compared to those of other Eastern European countries.

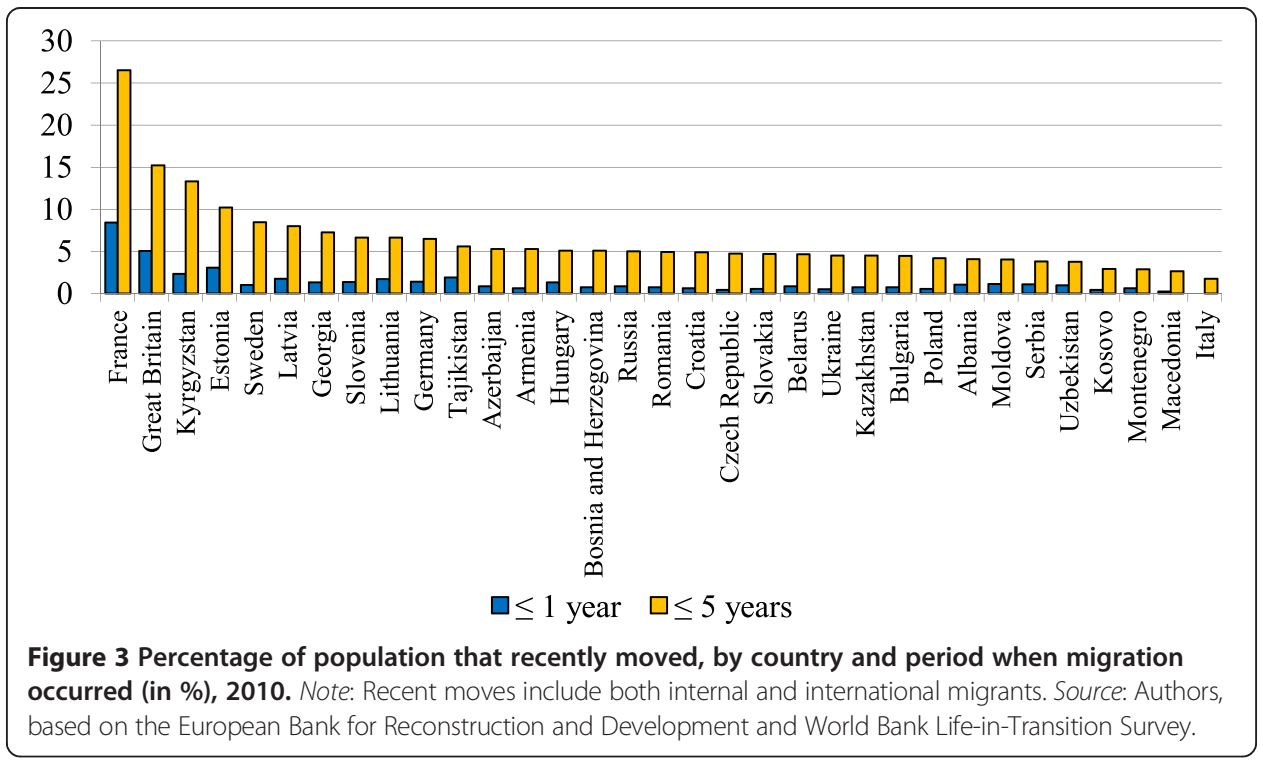


Table 1 Commuting rate as percent of the employed population (in \%), 2005-2010

\begin{tabular}{lllllll}
\hline & $\mathbf{2 0 0 5}$ & $\mathbf{2 0 0 6}$ & $\mathbf{2 0 0 7}$ & $\mathbf{2 0 0 8}$ & $\mathbf{2 0 0 9}$ & $\mathbf{2 0 1 0}$ \\
\hline Total & & & & & & \\
All commuters & 10.5 & 10.8 & 11.6 & 13.0 & 13.2 & 13.2 \\
Intra-regional & 9.2 & 9.5 & 10.2 & 11.1 & 11.6 & 11.6 \\
Inter-regional & 1.4 & 1.4 & 1.4 & 1.9 & 1.7 & 1.6 \\
Urban & & & & & & \\
All commuters & 6.7 & 7.0 & 7.2 & 7.5 & 7.0 & 7.2 \\
Intra-regional & 5.2 & 5.6 & 5.9 & 5.9 & 5.6 & 5.8 \\
Inter-regional & 1.5 & 1.4 & 1.3 & 1.6 & 1.4 & 1.4 \\
Rural & & & & & & \\
All commuters & 18.8 & 19.2 & 21.2 & 25.2 & 26.3 & 26.0 \\
Intra-regional & 17.7 & 18.0 & 19.5 & 22.6 & 24.1 & 24.1 \\
Inter-regional & 1.1 & 1.2 & 1.7 & 2.6 & 2.2 & 1.9 \\
\hline
\end{tabular}

Notes: Respondents temporarily working abroad are excluded.

Source: Authors, based on labor force survey data.

Only 3 respondents thought internal migration is high, while 4 respondents thought it was at the same level as in peer countries.

Therefore, all surveys confirm that Ukrainians are far less likely to move than workers in other countries. For those Ukrainians who move, one would expect that they move to the most dynamic regions. However, an examination of inter-regional migration data presents a further puzzle: even when Ukrainians do move, they do not always move to the most productive regions with high wages and low unemployment (Figure 4).

Ukrainians changing their place of residence within the country are more likely to move to communities located either within the same region (58 percent of all registered

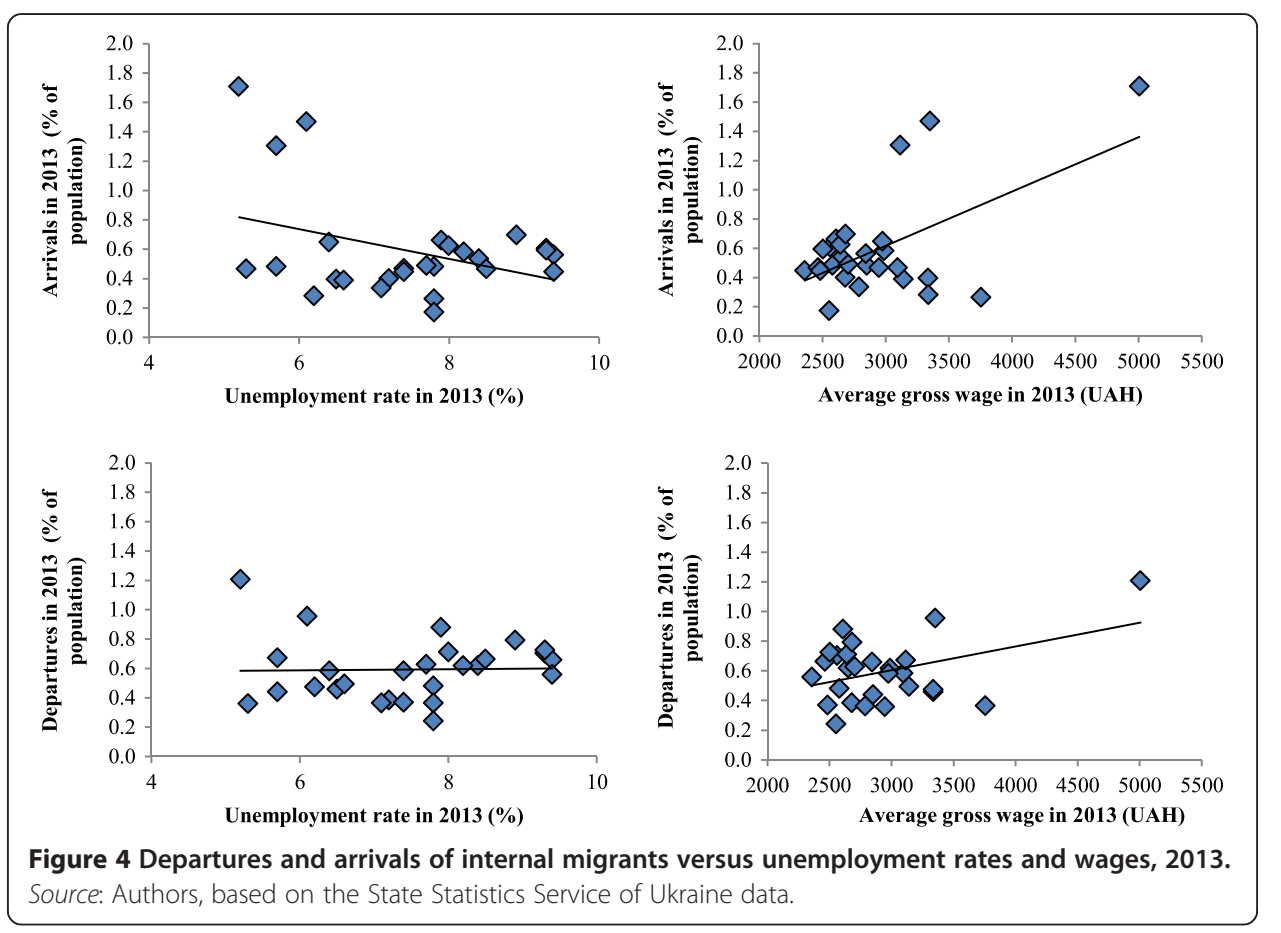


moves within Ukraine in 2012) or to neighboring regions (23.7 percent), which often have similar employment and income opportunities as the place of origin. Those who move to non-neighboring regions choose predominantly the capital city of Kiev, whereas moves between lagging and better-off regions located in different parts of Ukraine are relatively rare (Kupets 2014b). A positive and significant correlation between in-migration and out-migration rates indicates that high in-migration and outmigration rates are usually observed in the same regions, and therefore there is a great deal of churning rather than a genuine reallocation of people between regions.

In summary, Ukrainians do not migrate internally as much when compared to other countries, and those who move are not necessarily going to the regions with better labor market conditions. This begs the questions if there are constraints to internal labor mobility and what they are, which is the subject of the next section.

\section{Barriers to relocation of workers within Ukraine}

In order to answer these questions, we collected qualitative information using several methods: a Delphi-type survey among Ukrainian experts; focus group discussions; and consultations with Ukrainian policymakers, social partners, and representatives of local and international companies and business associations.

A short questionnaire consisting of 11 closed and open questions on internal mobility was sent to a panel of 46 experts; 19 fully answered questionnaires were returned. The respondents included four trade union representatives, four representatives from employers' organizations and eleven labor market and migration experts from think tanks and universities. The questionnaire focused on two main areas: (i) assessing perceptions in Ukraine on the magnitude and patterns of labor market mobility, and (ii) identifying of the most critical barriers to internal labor mobility in Ukraine.

Focus group discussions were aimed at better understanding the attitudes of migrant workers, the unemployed and employed towards internal migration, motivations to move, and the most salient barriers to internal mobility. They were conducted by the Kiev International Institute of Sociology between March and April 2012 with financial and technical support of the World Bank. There were two different sets of focus group discussions:

Two focus groups among migrant workers in Kiev City, one with highly-skilled employees/self-employed and the other with low-skilled workers. Nineteen participants filled in a prescreening questionnaire; sixteen participated in the focus group discussions. All participants had moved to Kiev for labor reasons from different regions of Ukraine. The two groups were balanced in terms of gender and age.

Seventeen focus groups were carried out among people with different labor market status as background work for the 2013 World Development Report (World Bank 2012b) and the accompanying country study for Ukraine (Kupets et al. 2012). The core questions discussed were about the employment situation in Ukraine, the meaning of a good job, people's appraisal of the availability and access to jobs, the role of jobs in social cohesion, coping strategies used by individuals and households when they are hit by negative shocks, and employment-related social relations between different social groups and generations. Internal and international migration was discussed as one of the possible coping strategies. The fieldwork was carried out in four different regions of 
Ukraine. In total, 157 informants participated in these discussions. Table 2 summarizes the key characteristics of these focus groups.

Although not representative and subjective in nature, this exercise provides an insight into the most binding constraints to internal mobility in Ukraine and the people's perceptions on the role of internal labor mobility for Ukraine's economic growth and development.

According to the experts' survey, there are indeed barriers to move. Fifteen out of nineteen experts indicated that given the regional differences in labor market outcomes in Ukraine, more people would like to move than actually did so for labor reasons. In other words, people are constrained in their decisions on internal mobility. The focus group discussions confirm this finding, with most participants indicating that they realized they could improve their job prospects by moving, but they often faced significant obstacles to migration.

In terms of what these barriers are, the experts list the population registry, lack of access to credit and the costs of migration, and the underdeveloped housing and mortgage market as the top three barriers (Figure 5). This finding is again confirmed by the

Table 2 Description of focus groups

\begin{tabular}{|c|c|c|c|}
\hline $\begin{array}{l}\text { Group } \\
\text { code }\end{array}$ & Short group description & Location & Date \\
\hline 1.1 & Highly-skilled internal migrants & Kiev & 30.04 .2012 \\
\hline 1.2 & Low-skilled internal migrants & Kiev & 30.04 .2012 \\
\hline$\| .01$ & Workers from a mono-industrial town & Ukrainsk, Donetsk oblast & 02.04 .2012 \\
\hline 11.02 & Unemployed women aged 45-50 & Donetsk & 31.03 .2012 \\
\hline 11.03 & & Lviv & 31.03.2012 \\
\hline 11.04 & Unemployed men aged 45-50 & Donetsk & 31.03.2012 \\
\hline 11.05 & & Lviv & 30.03.2012 \\
\hline 11.06 & & Simferopol, Crimean AR & 07.04 .2012 \\
\hline 11.07 & $\begin{array}{l}\text { University graduates entering the labor market } \\
\text { (one year after graduation), field of studies: engineering }\end{array}$ & Donetsk & 01.04 .2012 \\
\hline 11.08 & $\begin{array}{l}\text { University graduates entering the labor market (one year } \\
\text { after graduation), field of studies: information technologies }\end{array}$ & Lviv & 31.03 .2012 \\
\hline 11.09 & $\begin{array}{l}\text { University graduates entering the labor market } \\
\text { (one year after graduation), field of studies: sociology }\end{array}$ & Kiev & 27.03.2012 \\
\hline II.10 & $\begin{array}{l}\text { Highly skilled freelancers and self-employed/private } \\
\text { entrepreneurs (IT specialists, lawyers, journalists, } \\
\text { accountants, consultants, etc.) }\end{array}$ & Kiev & 26.03.2012 \\
\hline II.11 & Informally employed women (street market) from the city & Donetsk & 01.04 .2012 \\
\hline II. 12 & Informally employed women from the city & Lviv & 30.03.2012 \\
\hline II.13 & $\begin{array}{l}\text { Informally employed men (including casual workers in } \\
\text { elementary jobs, e.g. in construction) who are labor } \\
\text { migrants from the other parts of Ukraine to Kiev }\end{array}$ & Kiev & 26.03.2012 \\
\hline II.14 & Seasonal workers in agriculture & $\begin{array}{l}\text { Village Uyutnoe, Saky rayon, } \\
\text { Crimean AR }\end{array}$ & 08.04 .2012 \\
\hline II.15 & $\begin{array}{l}\text { Seasonal workers in hotels, restaurants, transport, and } \\
\text { other activities related to summer resorts }\end{array}$ & Evpatoria, Crimean AR & 08.04 .2012 \\
\hline II.16 & $\begin{array}{l}\text { Inactive people renting out their apartments during } \\
\text { the hot season }\end{array}$ & Evpatoria, Crimean AR & 08.04 .2012 \\
\hline$\| .17$ & $\begin{array}{l}\text { Youth aged } 20-24 \text { that are not in employment, education, } \\
\text { or training (NEET) }\end{array}$ & Village Vidnyky, Lviv oblast & 31.03 .2012 \\
\hline
\end{tabular}




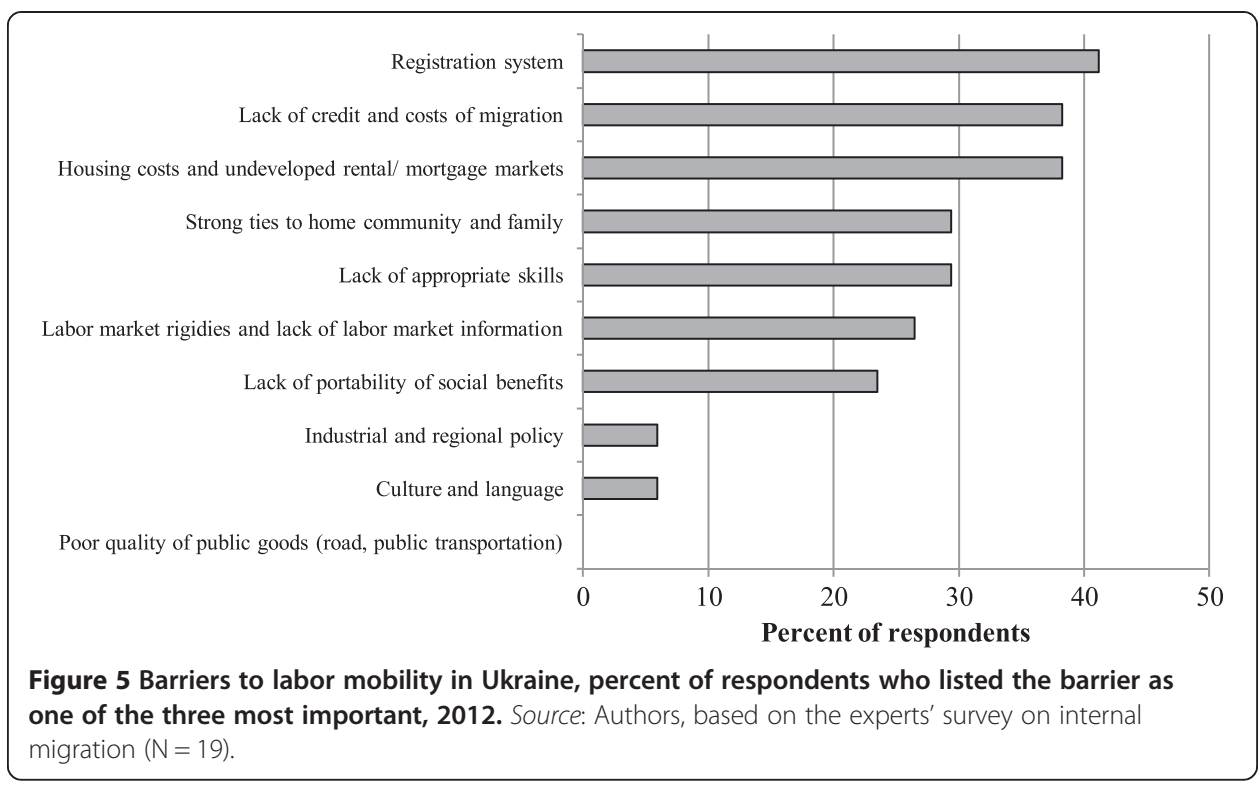

focus group discussions. Other potential barriers that featured prominently in both studies are skills, labor market institutions, and the design of social benefits. Interestingly, strong ties to families, friends and home communities, which were not directly mentioned among the suggested alternatives in the survey of experts, are also seen as critical factors hindering internal labor mobility in Ukraine. This is likely to reflect both affective ties to family and communities that bind people to their hometowns, but also the importance of informal social networks to find employment and housing and gather social support. It can be also the case that in view of relatively small differentials of income (adjusted by cost-of-living), workers simply do not have strong economic incentives to move far from their relatives and neighborhoods.

Surprisingly, industrial and regional policies, existing cultural and language differences between regions, poor quality of public goods and infrastructure (including roads and public transportation), ability (or inability) of migrants to integrate at new location, international migration as a substitute to internal migration are considered to be far less important obstacles to migration of workers within Ukraine. We will now discuss the main barriers in turn.

\subsection{Population registry}

A particular administrative obstacle to workers' mobility - in the form of a requirement that people register their place of residence - was cited most often by labor market experts and workers in our studies as critical in limiting internal mobility in Ukraine. This system of residential registration is an inheritance, albeit reformed, of the Soviet Union's old "propiska" system, which regulated the movement of people within the country.

According to the Law on Freedom of Movement and Free Choice of the Place of Residence in Ukraine (effective since January 2004), all residents have to register their place of residence with the State Migration Service within ten days of arrival at the new place of residence. The new place of residence is defined as the administrative-territorial unit where a person lives for at least 6 months during a year. To be registered, a person 
has to submit a written statement, internal passport, proof of a stamp duty payment, and two copies of the filled deregistration coupon from the previous place of residence. According to this law, it is prohibited to require any other documents for registration.

However, according to the Civil Code of Ukraine, the place of residence is defined as a place where a person permanently or predominantly lives as an owner, under the terms of the rental contract or under other statutory terms. Therefore, to be registered at a particular address (which is recorded then in the registration card and stamped in the internal passport), a person must provide grounds for registration. These grounds for registration are a property certificate, a rental contract, an authorization to occupy a publicly-owned apartment/house ("order") or the like. If there are no such documents, the official written consent from the property owner(s), if it is a private property, and from the household head and all the adult members of his/her family registered in this apartment/house, if it is a public or corporate property, is required.

If someone rents an apartment, he/she needs to provide an official rental contract. As became clear in the focus group discussions and in the consultations for this paper, both property owners and renters lack incentives to register rental contracts. For property owners, registering a contract would mean paying additional taxes on rental income and higher utilities costs which are linked to the number of people officially residing at an address. For renters, on the other hand, it would mean paying higher rents because of the aforementioned taxes and utilities. Since tax morale is generally low in Ukraine for a variety of reasons, the vast majority of people prefer informal rental agreements. The consequence is that these agreements protect neither the property owner nor the renter formally. Ultimately, it considerably increases uncertainty on both sides about the true price and the default risks of the rental agreement, and this uncertainty increases the costs of migration, especially to places further away from one's home.

Since the rental market is predominantly informal and the purchase of housing in attractive areas is usually too expensive, migrants most often do not have grounds to officially register at the new location. Individuals actually living at a particular address but who are unable to register may be prevented from access to public services. Although legally, residency is not a requirement for basic public services such as education and health care, many people still think this is the case, maybe due to the discretionary enforcement of the law or simple misinformation. However, this is a serious barrier for private entrepreneurs, voters, applicants to social assistance and housing subsidy, citizens willing to get some official document such as a driver license, tax identification code certificate, and so on because all procedures are tied to the official place of residence according to registration and the respective local office (tax administration, voting district, social assistance department, traffic police etc.).

Results from the focus group discussions echo these concerns regarding the registration system as an obstacle to migration. Difficulties and costs associated with the registration system ranked among the most significant problems encountered by low-skilled migrants. From the focus group discussions, it is also clear that migrants are not completely sure of when residency registration is a requirement:

"Usually, if you have children of pre-school or school age, registration is needed for placing children in a kindergarten or in a school. But in Kiev, this is not a problem. In Kiev, it is better with this issue than in other cities." (FG I.2) 
"Nowadays everything should be paid by patients in hospitals, that is why registration is not being asked." (FG I.2)

It should be noted that the registration system per se does not seem to constitute an overwhelming constraint to internal mobility because those who have decided to move have found ways around it. Some of the most popular strategies are: living with relatives or friends and getting their permission for registration; "owning" a miniature share of an apartment, often in non-existent places (with help of intermediaries for additional charge); and not registering at all, with bribing the decision makers if needed. These options, that help mitigate the deterrent effects of the registration system on internal migration, are available to many people. But they are costly and are, therefore, inefficient.

\subsection{Access to housing and credit}

For internal migrants, two elements are critical: having access to affordable housing and to affordable credit to cover migration costs. Housing-related constraints and limited access to credit are among the most critical barriers to internal mobility in Ukraine according to local experts (Figure 5). Reflecting this fact, focus group participants said that housing was the main obstacle keeping them from moving to places with better opportunities, especially to Kiev:

"For example, when I was working in my hometown, it meant that I lived at home, worked quietly, went to work, and had a small salary. When I arrived to Kiev, I needed to rent an apartment. This rent was very high...Almost all of my first salary went to rent." (FG I.1).

The Synovate survey (Synovate 2010), already mentioned in Section 3, underlines the problem. It found that while Ukrainians were less willing than Serbs or Bulgarians to relocate for a better job, this would change if they were provided with housing. In that case, more than half of the surveyed Ukrainians said they would change their mind and agree to move. In fact, Ukrainians explicitly cited imperfections in the housing market as the key constraint on their mobility. This is a powerful illustration of the housing market's importance in determining labor mobility in Ukraine.

There are several reasons why the housing market significantly affects Ukrainians' decisions to move (Komarov 2012). First, there is a very high home ownership rate. According to the Household Budget Survey in 2010, 95 percent of households owned the home they lived in, and only 2.4 percent of households reported that they rented their dwellings. This partly reflects a legacy from the first decade of transition when publicly owned houses and apartments were transferred to their occupants at little or no cost through privatization. Home ownership can discourage mobility because the perceived cost of staying in one's home, weighted against the anticipated transaction costs of relocating, is low. As income-migration elasticity is likely to be lower for homeowners than for renters, the former are less responsive to a higher salary of a new job. Personal attachments may also make it more difficult to give up an old house or apartment.

Second, there are significant housing price differentials across regions in Ukraine, with housing in leading regions being significantly more expensive than in lagging regions. These differentials make it difficult for people to sell their houses/apartments 
in lagging regions to finance the acquisition of similar ones at destination. Furthermore, wage or income differentials are not as large to compensate for significant differences in housing prices. To compare these regional differences, Komarov (2012) calculated the housing affordability index in all major cities as a ratio of the average price of an apartment of 54.8 square meters (which is an average usable area per dwelling in Ukraine) to the average annual disposable income per household and the average annual salary. He found that the most unaffordable housing both in terms of the disposable income and salary was in Lviv (11 and 22.5, respectively), Kiev (8.8 and 21.2) and Odesa (11.1 and 19.7) (Figure 6).

There are also significant regional differences in rental costs. Renting an apartment remains hardly affordable for households with a median level of income in most large cities of Ukraine. According to Komarov (2012), the most expensive rent of a benchmark one-bedroom apartment relative to an average household income in the end of 2010 was in Odesa (50.2 percent), Sevastopol (44.1 percent), Simferopol (43.4 percent), Donetsk (42.9 percent) and Dnipropetrovsk (37.4 percent). The relatively more affordable apartments to rent were in Zaporizhia (20.1 percent), Uzhhorod (22.5 percent) and Luhansk (22.8 percent). Due to liquidity constraints, many people cannot leave the poorest regions simply because they are unable to finance the cost of new housing in attractive destinations.

Third, housing in Ukraine is very expensive overall, representing on average more than 15 times annual income (Figure 7). This is the highest ratio in the ECA region after Lithuania and Belarus and seven times higher than in the United States.

Housing-related issues have been found to increase the cost of internal mobility and reduce the incentive to move in other countries as well. Home ownership has often been associated with decreased labor mobility (Bloze 2009; Fidrmuc and Huber 2003; Green and Hendershott 2001). In addition, the availability and cost of housing in other regions helps determine internal mobility (Fidrmuc and Huber 2003; Ghatak et al. 2007).

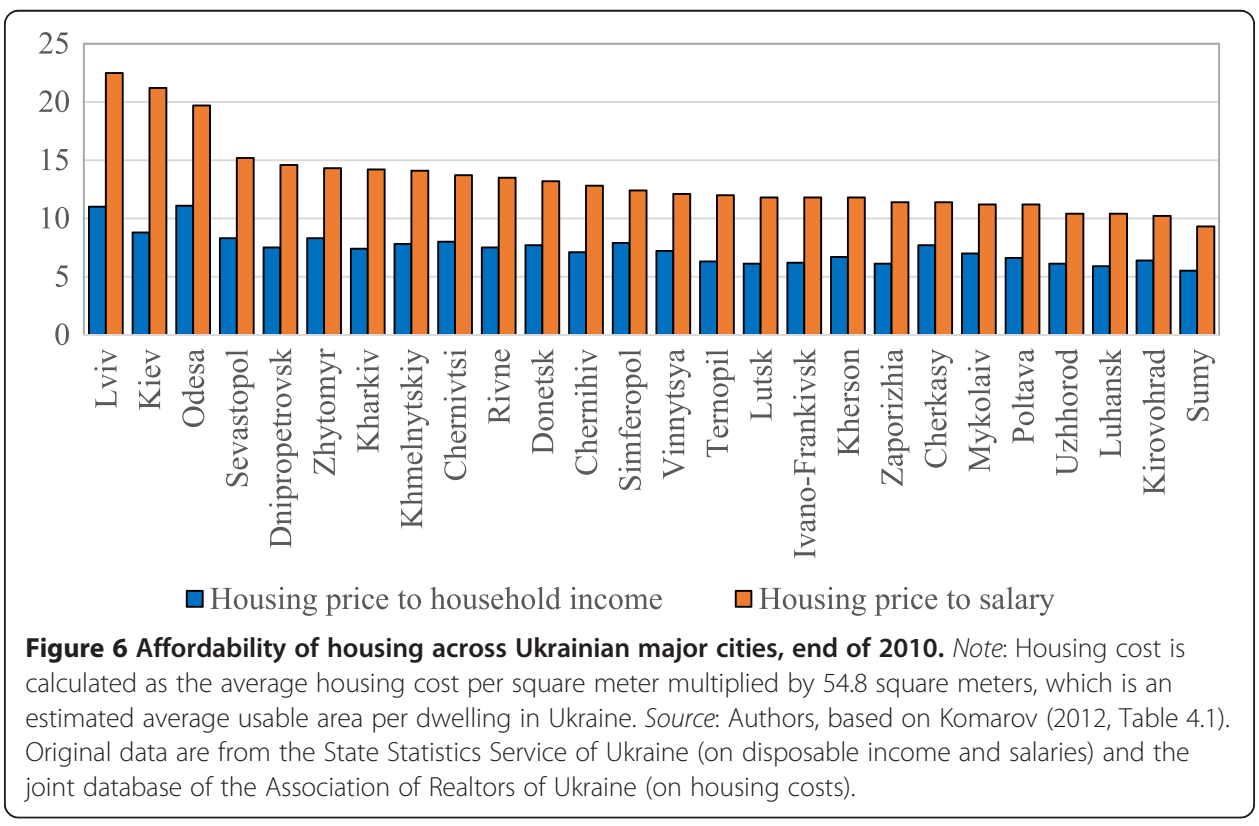




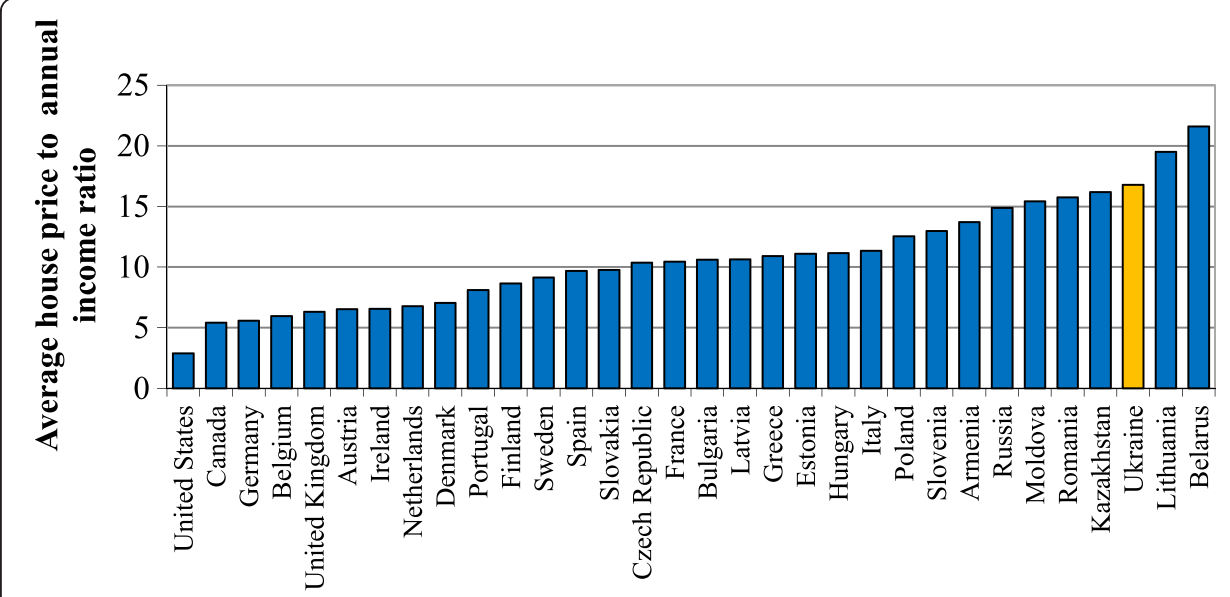

Figure 7 House price to annual income ratio in Ukraine and selected countries, 2010. Note: House price to income ratio is the ratio of median house prices to median annual disposable net wage, expressed as years of income. Median house price and median wages are taken on the basis of a sample of cities inside the country. For example, Ukraine is assessed on the basis of 16 cities, including all major oblast centers. For Russia, Poland and the USA, the number of surveyed cities is 24, 22, and around 240 cities, respectively. Source: Komarov (2012, Figure 3.1).

A fundamental constraint for affordable housing in leading regions is the lack of access to credit and underdeveloped mortgage markets. Financial markets, together with the services they provide, such as mortgages and other loans, are crucial for labor mobility (Hoj 2011; Coulson and Fisher 2009; Haurin and Gill 2002; van Leuvensteijn and Koning 2004). Well-functioning credit markets can help both in financing the move itself and also in financing housing arrangements at destination. They can be particularly useful in countries like Ukraine, where there are significant price differentials in housing across regions. Improvements in the credit and mortgage markets that result in lower interest rates are likely to have a feedback effect on housing prices.

Yet, Ukraine has a small mortgage market, with basic legislation passed only in 2003. Mortgage lending gained momentum in Ukraine in 2005 while most CEE countries experienced the start of the mortgage boom in the early 2000s. Residential mortgage debt increased sharply during the pre-crisis years and reached its peak of 11 percent of GDP in 2009 (Komarov 2012). This is comparable to the rates in Bulgaria and Slovenia but significantly below those in many other EU and OECD countries. The share of real estate transactions involving mortgage loans in the first quarter of 2011 was about 7 percent of the total number of transactions. This is about 3 percentage points more than in 2010 but over 10 times less than that of the "pre-crisis" year of 2007. The main factors behind low mortgage activity in Ukraine are uncertainty of borrowers in their financial stance and extremely high interest rates reflecting substantial political, economic and inflationary risks. Additionally, banks have tightened up their mortgage requirements regarding the loan value and debt servicing payment-to-income ratio and supporting documents, in response to the weak legislation protecting creditors' rights and difficulties in forced eviction of mortgagees unable to serve their loans if kids (up to 18 years old) or other vulnerable groups of people are registered there, particularly after the anti-crisis measures taken by the Ukrainian authorities in 2008-2009.

It is also important to note that before the economic and financial crisis that hit Ukraine in the end of 2008, most households preferred USD-denominated mortgage 
loans (less often in Euro or Swiss franc) due to much lower interest rates compared to $\mathrm{UAH}$-denominated loans, even though they received their income in $\mathrm{UAH}^{5}$. After almost 40 percent devaluation of the UAH in the second half of 2008 , these households faced serious problems with loan payments, and they continue facing similar problems thereafter ${ }^{6}$. As a result, the quality of a mortgage portfolio has deteriorated substantially, with nonpreforming loans of over 20 percent in total mortgage lending (Komarov 2012).

Further development of mortgage lending in Ukraine is suppressed by the poorly functioning financial market, which suffers from the lack of long-term funding due to the shallow domestic capital market, absence of institutional investors (e.g. pension funds), and high macroeconomic volatility. Before the global financial crisis, main sources of mortgage funding were short-term deposits and external borrowing (either in the form of Eurobonds or credit lines provided by parent banks to their subsidiaries in Ukraine). But reliance on such sources made the Ukrainian banking system heavily exposed to interest and foreign exchange risks.

Underdeveloped mortgage and credit market leads to high out-of-pocket payments from households' savings or borrowings from relatives, friends or informal intermediaries to cover reallocation costs from one place to another. This is likely to be a tall order for internal migrants, especially youth and the poor.

\subsection{Lack of skills}

Ukraine has a considerable skills mismatch, with an oversupply in certain occupations (laborers, sales and services, skilled agriculture) and concurrent undersupply in others (certain groups of professionals, particularly health workers; craftsmen and machine operators). Skilled labor shortages have become the second most commonly reported constraint to growth in the enterprise surveys across all countries in the Eastern Europe and Central Asia region (World Bank 2011a). On average, 30 percent of firms considered education and skills to be a major or severe constraint in 2008. Also, it takes firms considerably longer in Ukraine to hire workers with the required skills than in other countries in the region. This is especially true for skilled and non-production workers (World Bank 2009b).

Increasing internal labor mobility can help improve the matching process in the labor markets, but the lack of appropriate and easily transferable skills seems to be a serious obstacle to moving, as suggested by experts' survey (Figure 5). This concern was also echoed in the focus group discussions. As one participant puts it:

"At home I do get a low salary. But, it is impossible to find a job elsewhere in line with my field of expertise." (FG I.2).

These findings are supported by results from the labor force survey: the composition of jobs even by 1-digit occupation group in the regions with higher wages is significantly different from those in lagging regions (Figure 8). For example, in Ternopil oblast - the region with the lowest average wage in Ukraine - the share of unskilled jobs (elementary occupations) is over 45 percent, whereas the share of the first two groups (Legislators, senior officials and managers and Professionals) is 18.5 percent. In Kiev City, which is the leading region in many respects and the main destination for migrants, the similar shares are 4.7 and 50.6 percent, respectively. Therefore, workers from the lagging regions willing 


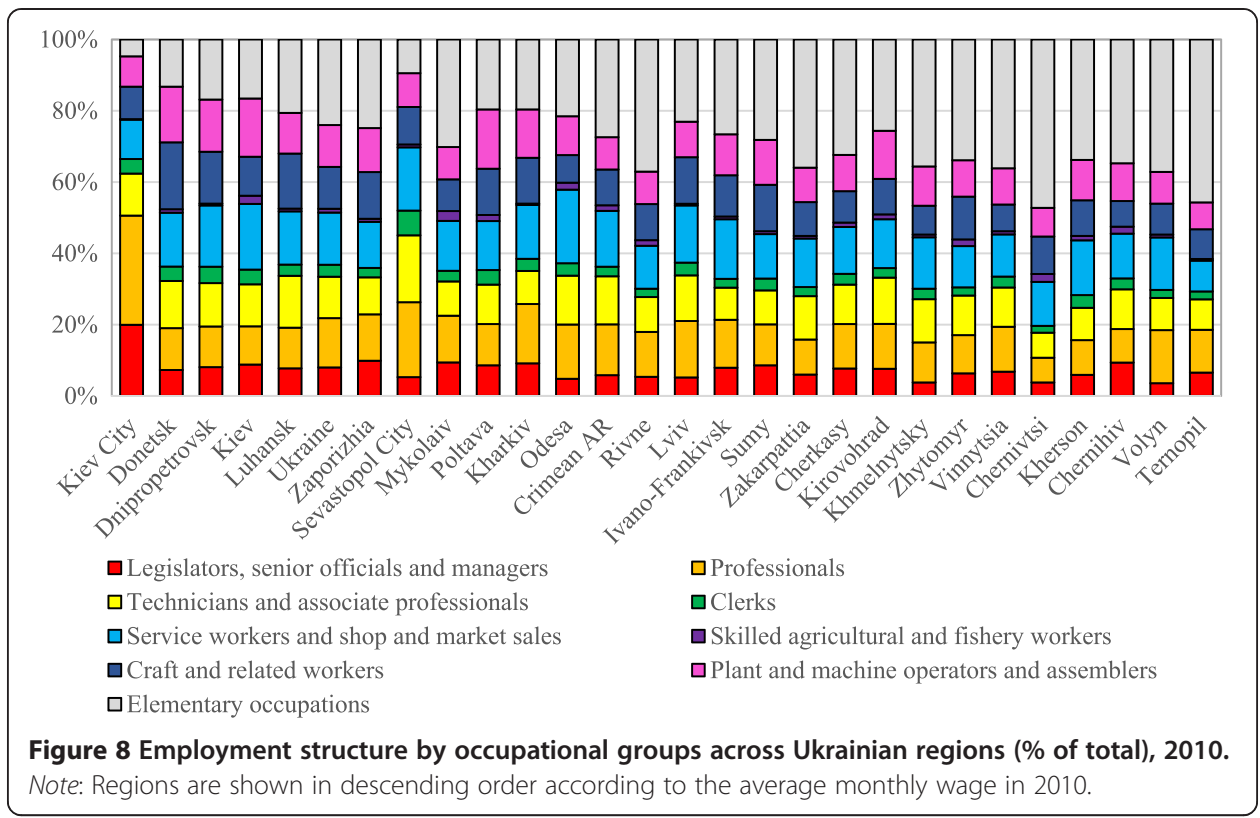

to get the most productive jobs in leading regions are very likely to lack the skills demanded at these jobs that certainly discourage them from reallocation.

Inadequate basic computer and search skills of workers also deter labor mobility as they limit access of job seekers to information about vacancies in other settlements/ regions available on the Internet (e.g. all-Ukrainian job portal maintained by the Public Employment Service of Ukraine) and contribute to informational asymmetries. The information barrier is particularly important in Ukraine due to the weakness of formal channels for the exchange of labor market information and abundance of informal jobs, information about which is not easily available.

The issues of demand and supply of skills (technical, cognitive and non-cognitive), skills mismatch and overeducation, and their role in employability, earnings and labor mobility have been understudied in Ukraine for data reasons. Hopefully, the ongoing studies based on the recent STEP survey conducted by the World Bank, the latest wave of the Ukrainian Longitudinal Monitoring Survey and the labor force survey will help fill this gap in the literature.

\subsection{Labor market institutions}

The importance of strong labor market institutions for internal labor mobility is motivated by two facts: first, the lack of dynamism in the Ukrainian labor market, as documented by much lower job creation and reallocation rates than in peer countries (World Bank 2009b); and second, the evidence that informal practices act as a partial, but at times, inefficient substitute for formal institutions in the labor market.

For workers to move, a fluid labor market is essential. High job turnover rates, in terms of recreation of existing jobs and the creation of new ones, increase the chances of employment and the quality of matching between employers and workers. If labor markets are static, people have fewer opportunities to change jobs and, therefore, fewer incentives to look for and move to better jobs, especially when far from home. 
Labor market regulations, such as employment protection legislation (EPL), that regulate the hiring and firing process of workers, are a critical determinant of the dynamism of labor markets. Overall, the available evidence in the literature on the impact of labor market institutions and policies on labor market outcomes remains inconclusive and often contradictory. In a comprehensive study of this impact in the transition economies of Eastern Europe and Central Asia, Lehmann and Muravyev (2012) found a robust negative effect of stricter EPL on the employment-to-population ratio and a significant positive impact on youth unemployment. The tax wedge is also found to have a strong depressing impact on the employment-to-population ratio, but not on any of the unemployment types, a result that was interpreted by the authors as "a scenario where high labor costs push workers into informal employment". In Ukraine, where the overall EPL, and protection of regular workers in particular, is very stringent compared to the other successor states of the Soviet Union (Muravyev, 2014), it is an important force deterring dynamism in the labor market and therefore labor mobility.

Ideally, EPL should provide a balance between the much needed flexibility to increase the dynamism of the labor market while offering sufficient protection to workers to have a proper safety net that facilitates labor market transitions. In Ukraine, this balance is not provided, enforcement of the old Labor Code adopted in 1971 is very weak, and employers tend to abuse their power, as confirmed by focus groups discussions for the Ukraine case study on jobs (Kupets et al. 2012). If provisions of EPL that regulate the terms of labor contracts, including the length of contract, payment of wages, working conditions, notice periods for layoffs, and severance pay, are enforced, they ensure a necessary level of security and certainty that increases the expected payoff from labor market decisions, including labor migration ${ }^{7}$. If workers do not have this security because of informal employment or abuse of power by their employers, they are deterred from moving to take up such insecure jobs. The uncertainty of payment of wages and fake probation periods are the most widespread problems mentioned during focus group discussions that adversely affect migration decisions:

"Basically, 90 percent of the construction sector here is in the shadow. And those 10 percent, which are not... Everyone here knows how many guys they employ, these people work 2-3 months and quit, new guys work 2-3 months and quit, and so on. Just because they are not getting paid for their work" (FG II.6)

"Many friends who got a job, mainly found through the Internet, say that they have a probation period. A month, two, three months... After all, employers do not pay because they tell them that they are not satisfied with people's work and say to them "good-bye". Next people come for 2-3 months, next, and so on." (FG II.10)

Besides, strict EPL and inefficient labor market institutions support the existing nationwide wage and labor market rigidities, which limit cost-of-living adjustments in regional wages and, therefore, decrease the net benefits of migration to the leading regions where, as has been shown above, housing and also living costs are much higher. Finally, other by-products of inefficient formal labor market institutions, namely gender, age and ethnic discrimination, work-related violence and exploitation of migrant workers, particularly widespread among the low-skilled, also hamper the ability of 
people to find decent employment in the other regions and therefore trap them in their low-productive jobs or unemployment in lagging regions.

\subsection{Social benefits}

Just as with labor regulations, social benefits can either discourage or encourage the open movement of labor. Well-designed unemployment insurance and social assistance benefits can help people overcome financial constraints and secure work in leading regions. On the other hand, poorly designed social benefits may prevent people from entering the labor market and may drive them to remain in lagging areas.

Overall, the social assistance sector has substantial coverage in Ukraine - with over 42 percent of the population receiving directly or indirectly at least one type of social assistance - and has poor targeting performance. Although the overall spending on social assistance went up before the crisis in 2008, there was a contraction of the income-tested program for low-income families in favor of categorically targeted programs such as child-related allowances, privileges to different categories of population, and allowances for people with disabilities. As a result, the overall targeting accuracy of the social assistance sector in Ukraine had deteriorated by 2008, and Ukraine became one of the poorest performers in the Eastern European and Former Soviet Union countries in terms of overall targeting accuracy and cost-effectiveness in alleviating poverty (World Bank 2010).

The receipt of social transfers may alter the labor and migration behavior of household members in two ways. On the one hand, they may reduce their work efforts and stop searching for (better) economic opportunities in other regions because transfers reduce the pressure to work and the rewards from working, particularly if benefits are reduced when household income increases (Grosh et al. 2008). On the other hand, beneficiaries may use the transfer to finance reallocation, cover job search costs, invest in training or small business, etc. But the empirical evidence suggests that participation in social assistance programs has only small or moderate effects on employment in developed countries, and even smaller effects in developing countries, where due to low generosity, most social assistance programs complement rather than substitute for the earnings of able-bodied beneficiaries (Grosh et al. 2008).

This is especially true for the programs with moderate generosity when the benefits represent less than a quarter of household income, as in Ukraine (World Bank 2010). The childbirth grant is probably the only prominent exception in terms of generosity, which seems remarkably high when compared to spending on other beneficiaries. In rare cases, it might indeed prevent people from moving, especially when taking into account the higher purchasing power in lagging and rural areas, but it is not likely to be the main reason against migration.

Another important barrier to internal labor mobility could arise from eligibility criteria for social benefits. If the eligibility is tied to the place of residence, and the benefit is not portable across regions, it could prevent people from moving. Technically, this is not always the case in Ukraine. For example, people can apply for and receive unemployment insurance regardless of where they live; the same is true for access to education and health care services. However, the application to social assistance and various benefits requires personal office visits at the place of official residence. To the 
extent that people are often not officially registered at the place where they actually live, this might require more or less frequent trips to the place of origin and could act as a - albeit probably small - disincentive to move. These concerns were confirmed by informants of focus groups discussions and our survey of experts (Figure 5).

\subsection{Social networks and informal arrangements}

As discussion has shown above, people in Ukraine face significant barriers when deciding to move. The institutions that are supposed to help people connect to economic opportunities in other regions - housing markets, government institutions like the population registry, labor market institutions, education and social welfare systems - are underperforming. As a result, Ukrainians often have to rely on alternative solutions, which are mostly unregulated and do not provide formal protection, entail high levels of uncertainty, and use social networks in lieu of formal institutions.

Social networks can be an efficient way of overcoming some of the barriers to internal mobility, but not always. The housing market is a good example. When searching for housing, using social networks can be a very efficient means. But social networks are typically tighter in the close proximity of one's home and therefore an important complement to other channels. But further away, they will be less tight and hence less efficient, and relying only on social networks alone can limit one's options. A fluid and transparent formal housing market is also needed.

The labor market is another, even more telling example. As with housing, social networks can be an efficient complement to formal search channels for jobs. But relying on social networks alone as a substitute for formal search channels limits people's options with regard to job search and could prevent them from connecting to better economic opportunities. The large extent of informal employment in Ukraine further limits people's horizons. Individuals circumvent the formal institutions of the labor market and either work informally or underreport their wages. As a consequence, the payment of wages is associated with high levels of uncertainty, as the focus group discussions show. When looking for a (new) job, Ukrainians use their social networks to get reassurance about the reliability of their prospective employer with regard to promised wage payments and working conditions. If there is no such reassurance, the risks and hence the costs of migration are higher.

Social protection and access to credit are the last examples. In the absence of effective formal social protection mechanisms that support risk management, people will have to rely on informal social risk management mechanisms. Or, in the absence to formal access to credit, they will have to rely on families and friends for loans, including for financing migration. Strong ties to local communities are essential to have access to these informal risk management mechanisms and access to credit. Again, these can be valuable complements to formal institutions, but if they act as a substitute to formal institutions, they can either hold people back, or, maybe even more importantly, influence migrants' destination decisions since people will prefer to go where they can build on an existing network. This might not necessarily be where the economic opportunities are.

\section{Policy implications: removing the barriers to internal mobility}

Increasing internal mobility in Ukraine is crucial given the challenges it faces in the future: a rapidly declining and aging population. Ukraine's population is declining faster 
than in in almost any other country in the world, due to high mortality, low birth rates and outmigration. Ukraine's population is projected to fall below 35 million by 2060 (from current 45 million), and over a quarter of the population are expected to be aged 65 years and older by then. If gender-age-specific labor force participation rates remain constant at 2010 levels, Ukraine is expected to lose over 8 million economically active people aged 15 to 64 years between 2010 and 2060, or over 39 percent of its 2010 level (Kupets 2014c). Hence, demographic shifts will have a strong impact on Ukraine's labor market and medium- and long-term economic growth prospects. Greater workforce mobility and better utilization of available human resources across the country are likely to help mitigate their impact.

In order to make Ukrainians more mobile and create the conditions necessary to complete the transition to a market economy, it is important for the government to make lasting changes in policy and create effective institutions that support labor mobility rather than standing in the way. Each change will have a ripple effect on the others, and together they will simplify the current system, reduce uncertainty, and provide protection for workers.

\subsection{Reform the registry system}

In the previous section, we listed the population registry as one of the major barriers to moving in Ukraine. Although many people have found ways around the inefficiencies created by the registration system, reforming it could change people's perceptions about the barriers to moving and reduce inefficiencies in other markets, such as housing/ rental, which may also limit internal mobility.

Organization for Security and Co-operation in Europe (2009) provides useful guidelines on population registration, setting out the main principles for the establishment and maintenance of functional models of population registration in democratic societies, describing criteria for developing efficient population-registration systems that correspond to the actual needs of the member states and their citizens, and highlighting good practices in the region. Ukrainian authorities and practitioners should follow these guidelines in reforming the national system of population registration. It is important to ensure that after reforming the system, citizens can actually exercise the fundamental human rights guaranteed by the Constitution of Ukraine and international legal instruments, such as those regarding the freedom of movement and free choice of the place of residence; access to social public services like education, health care, and social assistance; the right to vote; privacy and property rights, etc.

But reforming the registration system is not only about changing the legal framework or computerization of the system, it is also about strict implementation of the rules and procedures by all the relevant institutions and removing the incentives for individuals to provide false information about the place of residence or circumvent the system at all. On top of this, there should be public trust and confidence in government and political institutions, which has been very low in Ukraine (Kupets et al. 2012) and which triggered the civil unrest and political turmoil in 2013 - 2014 (Besedina 2014). Building trust of Ukrainians in their government and political institutions by improving governance, fighting corruption, reducing income inequality and strengthening the civil society is, therefore, the first step to increase the willingness of citizens to register their actual place of residence and declare their economic activities/income to the state. 
True reform of the registration system also requires coordinated actions from the tax system and the housing/rental markets. Improving the incentives for registering rental contracts would create the necessary institutional backdrop for making renting more transparent and more attractive.

\subsection{Ensure a better functioning housing market}

Ensuring a better functioning housing market - including its complementary markets such as real estate, rental and credit markets - is fundamental in addressing existing barriers to internal labor mobility in Ukraine. Komarov (2012) suggests a detailed list of policy options directed at improving the overall functioning of these markets in Ukraine. The key area is the development of the rental market, with the necessary reorientation of the state housing policy goals from promising free homeownership to everyone to providing households with more and better opportunities of rented housing. Komarov (2012) offers the following two supplementary alternatives for developing the public rental sector in Ukraine:

(i) social housing, to be rented out by local authorities to low-income households, disabled, homeless people and other socially vulnerable citizens, at fairly low rates that are largely subsidized by local authorities, and

(ii) affordable housing, i.e. housing offered for rent to the households which are not poor enough to claim social housing but which are not rich enough to buy an apartment/house or get a mortgage loan. Dwellings for affordable housing can be provided from a municipal stock but mainly at the expense of private resources mobilized in the framework of a public-private partnership, funds provided by non-profit organizations and private investors. Amann (2005) suggests to follow good practices of Scandinavian countries, the Netherlands and Austria by establishing an intermediary organization between the market and the state like Housing Finance Agency (so-called Third Sector in housing), which acts in accordance with the market economy principles but helps fulfill policy targets of the state.

The Austrian model of social housing and its financing, with the Limited Profit Housing Associations acting as the Third Sector in housing, has proved to be one of the best models to follow by Central and South Eastern European countries (Amann and Mundt 2005; Amann 2010). A definite advantage of the Austrian social housing model is that it does not restrict policy measures to low-income households, and, as a result, there is a high level of equality in housing cost, quality of settlements and available space and almost no segregation (Amann and Mundt 2005). In addition, competition between the large social housing sector and the private segment of the rental market influences the general price level and fosters overall efficiency in the housing market.

Imposing a real estate tax in Ukraine as a stimulus for housing supply in the higherdemand areas is another promising reform. Without a real estate tax, housing is historically treated as a relatively inexpensive consumption commodity by many insiders (e.g. poor elderly citizens). The imposition of a real estate tax would change the perception of housing from a consumption good to a capital good and expand the rental market for rooms, apartments and houses. This could be particularly beneficial as a source of 
affordable housing for potential migrants. The real estate tax is also worth considering because in addition to being a source of revenue, it is beneficial for decentralization of public finances - a policy goal that is being pursued by the Ukrainian government with the donor community, and is on the top of the current reform agenda.

The imposition of the real estate tax on 1 January 2013 was envisaged by Article 265 of the New Tax Code of Ukraine, but in mid-2013 it was postponed until 1 January 2014. According to the recent amendments to the Tax Code effective since 1 April 2014, the tax base is the total area of a residential real estate property. For individuals, the tax base may be reduced by 120 square meters for apartments and by 250 square meters for a house. The tax is heavily criticized by experts because of low tax rates ${ }^{8}$ and because its base is linked to an apartment size (in square meters) rather than to a market value of the property, which is at odds with standard practice in the world. Furthermore, as usual in Ukrainian legislation, there are many tax exemptions ${ }^{9}$. Hence, it is not a full-fledged property tax that would deliver substantial revenues to local governments and contribute to the efficient reallocation of people between dwellings, municipalities and regions, as in developed countries. This calls for further improvement of the real estate tax in Ukraine, following good practices in the world.

Finally, concerted actions are also needed in the land and financial markets. Currently, distorted land markets (with land and urban zoning restrictions as a speculative asset for shadow economy receipts) and shallow financial markets (with lacking or unaffordable credit for developers and private investors) limit the construction of new and affordable housing. Development of a sustainable mortgage and credit market requires reduction of macroeconomic risks and inflation; creating more options for long-term funding, for example through increased participation of institutional investors in the framework of pension and stock market reforms; improving the legislation regarding the problems of non-performing loans and protection of creditors' rights; etc. The state could also give an impetus to mortgage market development through a restoration of mortgage bonds issued for refinancing of commercial banks through the State Mortgage Institution or a mortgage broker company based on state-owned or commercial banks (Komarov 2012). Overall, policies should support deeper mortgage lending while managing risks better.

\subsection{Invest in skills development and education}

In order to facilitate labor mobility, people need to be equipped with skills that are transferable across sectors and occupations. For this, people need to have the ability to acquire new knowledge, and for that they need a good foundation of cognitive and non-cognitive skills. For the younger generation, this base of strong cognitive skills can be provided by the education and training system. For the stock of current workers who are already out of the formal education system, the policy challenge is to find effective ways to provide these foundations and encourage re-training in new, modern occupations.

Many of the challenges inherent in improving skills in the workforce and reducing the skills mismatch can be addressed through effective policy interventions in postsecondary education. As discussed extensively in a World Bank report on skills in Eastern European and Central Asian countries (World Bank 2011a), such interventions should focus on overcoming failures in information that lead many people to make sub-optimal 
skills investments (for example, when few people acquire the skills needed to become engineers, physicists, family therapists, skilled craftsmen that are in high demand and prefer instead "fashionable" fields such as finance, economic sciences, law, political science, etc.) and on quality assurance.

Ukraine also needs to improve the efficiency of its elementary and secondary education systems. It has struggled to reorganize its school networks in the face of shrinking student cohorts, resulting in a misallocation of scarce resources, for example, in maintenance of nearly empty schools rather than in restoring the attractiveness of the teaching profession (Coupe et al. 2011). Reallocating resources would enable the system to provide a good grounding in the skills most needed in a knowledge-based economy. It is also necessary to ensure that pre-school and basic education curricula and pedagogic practice pay adequate attention to the critical development of cognitive and non-cognitive skills. This is important when it comes to setting learning standards and targets, training teachers, and when assessing learning in both cognitive and behavioral dimensions. The experience with related reforms and interventions in Europe and the rest of the world can offer useful lessons.

To meet the challenge of retraining workers, the education and training system needs to become more responsive to labor market needs. This will require more direct involvement of the private sector in the design and provision of education and training and a more active role in providing young workers and older trainees with on-the-job learning and training opportunities. At the same time, workers need to have better access to appropriate labor market data, like prevailing wages, career advancement opportunities, and vacancy rates in order to make informed decisions about their educational investment. Labor market observatories and public and private labor market intermediaries should play an important role in providing this information, especially for potential internal migrants. Life-long learning also becomes increasingly important, given the demographic trends.

In short, it is the formation of the right skills rather than diplomas, efficiency rather than the amount of spending on education, quality rather than quantitative education indicators that should be the focus of reforms of the education and training systems in Ukraine. To that end, though, more evidence is needed on the learning and employment outcomes of students, graduates and adult workers in order to inform policy design and monitoring.

\subsection{Rebalance labor market and social welfare institutions}

As follows from discussion in Section 4.5, institutional reforms of the labor regulations are extremely important for creating a dynamic labor market in Ukraine. The current labor code that dates from before the transition needs to be replaced by the new one an issue that has been on the top of the legislative agenda since 2001 but without positive outcome so far. In addition, there are many reforms in the field of labor inspection services, labor taxation, and governance that are also needed in order to reduce informality and improve the overall labor market functioning (World Bank 2011b). The challenge is to rebalance labor regulations to provide the much needed flexibility to increase the dynamism of the labor market while offering sufficient protection to workers to have a proper safety net that facilitates labor market transitions. 
As with labor laws, the key for social benefits is to balance the amount of the benefit aimed at support of low-income households with the disincentives it might create to participate in the labor force and seek economic opportunities in leading regions. It is also important to ensure that the eligibility criteria for social benefits and services do not bind people to their current place of residence, and the benefits are easily portable across the country. In other words, existing social benefits and services should be spatially blind in their design and universal in their coverage - i.e. made available to every eligible person or household regardless of its location (World Bank 2009a). In Ukraine, there is also room to reconsider the design of some not well targeted social assistance programs to improve the equity of the social welfare system and save costs that can be channeled into other important programs or areas (World Bank 2010).

\section{Conclusion}

Ukraine's economy lacks dynamism, with job creation and reallocation rates significantly below those of its peers. This is both the cause and the effect of people not moving. The rate at which Ukrainians move from one region to another within the country is only half of what we would expect it to be when comparing to other countries. Yet even this small stream of mobile workers in Ukraine does not flow to leading regions. Migrants are not leaving lagging areas with poor labor market outcomes, and they are not necessarily going to regions with better job conditions. This suggests that certain barriers prevent people from seeking economic opportunity but also that significant gains could be realized from greater internal labor mobility.

The main barriers to internal mobility in Ukraine are institutional: (i) administrative procedures that require people to be officially registered at their place of residence, although many people prefer not to register a new residence for various reasons; (ii) underdeveloped housing and credit markets, which make it difficult for people to rent or buy housing in leading regions; (iii) inadequate human capital, as people in lagging regions often lack the necessary skills to access better economic opportunities in highproductivity, modern sectors in the leading regions; (iv) weak formal labor market institutions that reduce dynamism in the labor market, stimulate informal work arrangements and do not provide workers with enough reliable information about job openings and labor market conditions; and (v) social benefits and services that are often tied to the place of residence and that could, in some cases, discourage labor force participation and work efforts in the first place.

Addressing these institutional bottlenecks that affect internal mobility will allow people, especially the poor, to access more and better jobs in leading regions. We suggest five key areas for improvement aimed at helping workers to freely pursue job opportunities throughout Ukraine. First, the population registry system needs to be streamlined and modernized. Second, reforms are necessary to improve the functioning of housing and credit markets. Third, reforms in the education and training system aimed at equipping people with relevant and easily transferable skills are needed. Fourth, labor market institutions need to be improved in a way that will spur dynamism in the labor market while still protecting workers and will also provide reliable information about job openings and labor market conditions. Fifth, there is a need for modernization of the social welfare system to make social benefits easily portable across the country and more targeted at the most needy people. 


\section{Endnotes}

${ }^{1}$ Although population registers count migrations (events) rather than migrants (transitions), we use these terms interchangeably assuming that the share of multiple and return migration within a given year is negligible.

${ }^{2}$ Region here refers to the first-level administrative unit which is one of 24 oblasts, Autonomous Republic of Crimea or one of two cities with a special status (Kiev and Sevastopol). Taking into account the average size of Ukrainian regions (about 1,675,000 people in 2013), the administrative division of Ukraine into 27 units is consistent with the NUTS system and corresponds to its second level (NUTS-2). This allows us to compare migration indicators in Ukraine to those in the EU member states.

${ }^{3}$ Regions are shown in descending order in terms of the net internal migrate rate in 2013.

${ }^{4}$ We compared internal migration rates in Ukraine (measured by administrative data at oblast and rayon level) with internal migration rates from other countries. For other countries, the internal migration rates are mainly measured through population registries or, at times, through surveys or the census. The comparison is done controlling for the average size and number of geographical units used to calculate internal migration rates. This is important because the number of migrants recorded fundamentally depends on the number and size of the units into which the territory is divided, and the differences in statistical geography can bias cross-country comparisons. Applying a log-linear trend line across the whole sample yields the expected internal migration rate for a given size of the unit of measurement.

${ }^{5}$ According to the National Bank of Ukraine, mortgage loans denominated in foreign currency made up 88 percent of total mortgage loans in 2010 (Komarov 2012).

${ }^{6}$ For example, from January 2005 to October 2008 the official UAH/USD exchange rate was between 4.84 - 5.3 UAH per 1 USD. In the aftermath of the economic crisis at the end of 2008, the local currency depreciated to about 8 UAH per 1 USD and remained pegged to this rate until the end of 2013. Political and economic turmoil in Ukraine in 2014, together with transition of the National Bank of Ukraine to a floating exchange rate regime in order to meet the IMF requests, turned the Ukrainian hryvnia into one of the worst performers versus the US dollar in the world, with depreciation over 13 UAH per 1 USD in October 2014.

${ }^{7}$ Interestingly, perceived job security in both temporary and permanent private jobs is found to be lower in countries with stricter employment protection legislation. This is probably because strict EPL seems to increase the associated cost of job loss by reducing the re-employment probability and extending duration of unemployment (Clark and Postel-Vinay 2009). At the same time, perceived job security in public jobs, which are usually "insulated from labor market shocks", is uncorrelated with the stringency of EPL.

${ }^{8}$ The fixed rate per square meter is set as a percentage of the minimum salary established by the law as of 1 January of the respective tax year. For residential apartments, the total area of which does not exceed 240 square meters, and residential houses, the total area of which does not exceed 500 square meters, the real estate tax rate for the property not being a land plot must not exceed 1 percent of the minimum wage. In case of an excess of the size of the above area, the tax rate shall be 2.7 percent. The first version of this regulation, effective before April 1, 2014, used only residential (living) area of the residential real estate object instead of its total area. 
${ }^{9}$ For example, pursuant to Article 265.2.2 of the Tax Code, the tax is not paid for: residential properties owned by state or territorial communities (their joint ownership); residential properties located in exclusion areas and unconditional (mandatory) resettlement as set forth by law; structures of a family-type orphanage; garden or dacha buildings (but their number should not exceed one such property per taxpayer); residential properties owned by families having many children and foster families having three or more children (but their number should not exceed one such property per family); and dormitories.

\section{Abbreviations}

AR: Autonomous Republic; EPL: Employment protection legislation; EU: European Union; GDP: Gross Domestic Product; IOM: International Organization for Migration; NUTS: Nomenclature of Territorial Units for Statistics; OECD: Organization for Economic Cooperation and Development; OSCE: Organization for Security and Co-operation in Europe; UAH: Ukrainian hryvnia (local currency); USA: United States of America; USD: US dollar; UNDP: United Nations Development Programme.

\section{Competing interests}

The IZA Journal of Labor and Development is committed to the IZA Guiding Principles of Research Integrity. The authors declare that they have observed these principles.

\section{Acknowledgements}

This paper is based on a report conducted as part of the World Bank's analytical and advisory services to Ukraine (World Bank 2012a). The findings, interpretations, and conclusions expressed herein are those of the authors and do not necessarily reflect the views of the Board of Executive Directors of the World Bank or the governments they represent. The authors are grateful to the Bank staff for valuable comments on the earlier drafts of the report, peer reviewers of the final draft, and administrative and logistical support. Vladislav Komarov contributed greatly through his background paper on the key features and weaknesses of the housing market in Ukraine.

The authors are also grateful to the anonymous referee for constructive feedback and suggestions to improve the paper. The authors also thank the participants of a World Bank dissemination workshop in Kiev in December 2012 and the KNOMAD Conference on Internal Migration and Urbanization in Dhaka in April-May 2014 for useful comments and suggestions.

Responsible editor: Hartmut Lehmann

\section{Author details}

${ }^{1}$ World Bank, 1818 H Street NW, Washington, DC 20433, USA. ²Department of Economics, National University of Kyiv-Mohyla Academy, 10 Voloska Street, 04070 Kyiv, Ukraine. ${ }^{3}$ World Bank Country Office in Moldova, 20/1 Pushkin Street, MD-2012 Chisinau, Republic of Moldova.

Received: 28 May 2014 Accepted: 21 October 2014

Published online: 10 December 2014

\section{References}

Amann W (2005) How to boost rental housing construction in CEE/SEE countries. Hous Finance Int J 12:24-31 Amann W (2010) New policies to facilitate affordable housing in Central and Eastern Europe. Acta Polytechnica 50(1):53-56

Amann W, Mundt A (2005) The Austrian System of Social Housing Finance. Available via IUT. http://www.iut.nu/ FindOutMore/Europe/Austria/Socialhousing_finance_Amman_Mundt.pdf. Accessed 17 September 2014

Besedina E Trust and economic reforms. Forum for Research on Eastern Europe and Emerging Economies (FREE) Policy Brief Series. Available via FREE. http://freepolicybriefs.org/2014/05/19/trust-and-economic-reforms. Accessed 17 September 2014

Bloze G (2009) Interregional migration and housing structure in an East European transition country: A view of Lithuania 2001-2008. Baltic J Econ 9(2):47-66

Brück T, Danzer A, Muravyev A, Weißhaar N (2010) Determinants of poverty during transition: household survey evidence from Ukraine. J Comp Econ 38(2):123-145

Clark A, Postel-Vinay F (2009) Job security and job protection. Oxford Econ Papers-New Series 61(2):207-239

Coulson N, Fisher L (2009) Housing tenure and labor market impacts: The search goes on. J Urban Econ 65(3):252-264

Coupe T, Olefir A, Alonso J (2011) Is Optimization an Opportunity? An Assessment of the Impact of Class Size and School Size on the Performance of Ukrainian Secondary Schools. World Bank Policy Research Working Paper No. 5879, World Bank, Washington, DC

Fidrmuc J, Huber P (2003) The Puzzle of Rising Regional Disparities and Falling Migration Rates During Transition. Paper Presented at the 18th Annual European Economic Association Congress and the 58th European Econometric Society, Stockholm. 20-24 August 2003. http://www.eea-esem.com/papers/eea-esem/2003/2010/FidrmucHuberESEM2003.pdf

Ghatak S, Mulhern A, Watson J (2007) Interregional Migration in Transition Countries: The Case of Poland. Economics Discussion Paper 2007/7, School of Economics, University of Kingston, London

Green R, Hendershott PH (2001) Home Ownership and the Duration of Unemployment: A Test of the Oswald Hypothesis. NBER Working Paper 2001/8/2, Cambridge, MA

Grosh M, del Ninno C, Tesliuo E, Ouerghi A (2008) For Protection and Promotion: The Design and Implementation of Safety Nets. World Bank, Washington, DC 
Haurin D, Gill L (2002) The impact of transaction costs and the expected length of stay on homeownership. J Urban Econ 51:563-584

Hoj J (2011) Improving the Flexibility of the Dutch Housing Market to Enhance Labour Mobility. OECD Working Paper No. 833, OECD, Paris

International Organization for Migration (2005) Migration, Development and Poverty Reduction in Asia. IOM, Geneva International Organization for Migration (2008) Chapter 7. Internal migration. In: World migration report (2008) Managing Labour Mobility in the Evolving Global Economy. IOM, Geneva, pp 173-199

Komarov V (2012) Housing Market and Labor Mobility. Available via World Bank. http://documents.worldbank.org/ curated/en/2011/09/17013326/housing-market-labor-mobility. Accessed 1 September 2012

Kupets O (2012) Statystychnyj analiz maiatnykovoi trudovoi mihratsii v Ukraini [Statistical analysis of commuting in Ukraine]. In: Formation of the Market Economy, Special Edition "Labour in the 21st Century: New Trends, Social Dimension and Innovative Development", vol 1. Kyiv National Economic University, Kyiv, pp 649-660. in Ukrainian

Kupets O (2014a) Do Ukrainians vote with their feet: Local public expenditures and inter-regional migration. Naukovi zapysky NaUKMA, Ekonomichni nauky [NaUKMA. Sci Proc Econ Sci 159:35-4]

Kupets O (2014b) Interregional migration in Ukraine: Spatial, economic and social factors. Demography Soc Econ 2:22. in press

Kupets O (2014c) Labor market challenges of an aging and shrinking population in Ukraine.J Comp Econ Stud 9.99-134

Kupets O, Vakhitov V, Babenko S (2012) Demographic Change. Jobs case study, Ukraine. Available via World Bank. http://siteresources.worldbank.org/EXTNWDR2013/Resources/8258024-1320950747192/8260293-1320956712276/ 8261091-1348683883703/WDR2013_bp_Jobs_And_Demographic_Change.pdf. Accessed 1 December 2012

Lall SV, Selod H, Shalizi Z (2006) Rural-Urban Migration in Developing Countries: A Survey of Theoretical Predictions and Empirical Findings. World Bank Policy Research Working Paper No. 3915, World Bank, Washington, DC

Lehmann H, Muravyev A (2012) Labor markets institutions and labor market performance: What can we learn from transition countries? Econ Transit 20(2):235-269

Martynenko T (2004) Regional Migration and the Evolution of Regional Unemployment Patterns in Ukraine. EERC (KSE), Kiev, Ukraine

Moretti E (2012) The new Geography of Jobs. Houghton Mifflin Harcourt, New York

Muravyev A (2014) The evolution of the regulation of labour in the USSR, the CIS and the Baltic states, 1985-2009. Eur Asia Stud 66(8):1270-1294

Myrdal G (1963) Economic Theory and Underdeveloped Regions. Methuen \& Co, Ltd, London

Organization for Security and Co-operation in Europe (2009) Guidelines on Population Registration. OSCE Office for Democratic Institutions and Human Rights, Warsaw

Paci P, Tiongson E, Walewski M, Liwirnski J, Stoilkova M (2007) Internal Labor Mobility in Central Europe and the Baltic Region. World Bank Working Paper No. 105, World Bank, Washington, DC

Sharpe A, Arsenault A, Ershov D (2007) The Impact of Interprovincial Migration on Aggregate Output and Labour Productivity in Canada, 1987-2006. Research Report 2007-02, Centre for the Study of Living Standards, Ottawa

Synovate (2010) Survey of Labour Mobility in Russia, Ukraine, Bulgaria and Serbia. Synovate, London

Vakulenko E (2014) Does migration lead to regional convergence on Russia? Working paper 53/EC/2014. Basic Research Program, National Research University Higher School of Economics (HSE), Moscow

van Leuvensteijn M, Koning P (2004) The effect of home ownership on labor mobility in the Netherlands. J Urban Econ 55(3):580-596

United Nations Development Programme (2008) Human Development Report. Human Development and Ukraine's European Choice. UNDP Ukraine, Kiev, Ukraine

World Bank (2005) Ukraine Poverty Assessment: Poverty and Inequality in a Growing Economy. Report no. 34631-UA. World Bank, Washington, DC

World Bank (2009a) World Development Report 2009: Reshaping Economic Geography. World Bank, Washington, DC

World Bank (2009b) Ukraine Labor Demand Study. World Bank, Washington, DC

World Bank (2010) Improving Targeting Accuracy of Social Assistance Programs in Ukraine. Technical Note for the Government of Ukraine. World Bank, Washington, DC. Available via World Bank. http://siteresources.worldbank.org/ UKRAINEINUKRAINIANEXTN/Resources/UkraineHMTNote.pdf. Accessed on September 17, 2014

World Bank (2011a) Skills, not Just Diplomas. Managing Education for Results in Eastern Europe and Central Asia. World Bank, Washington, DC

World Bank (2011 b) Policies to Reduce Informal Employment: An International Survey. Technical Note for the Government of Ukraine. World Bank, Washington, DC. Available via World Bank. http://siteresources.worldbank.org/ UKRAINEINUKRAINIANEXTN/Resources/455680-1310372404373/PoliciestoReducelnformalEmploymentEng.pdf: Accessed on September 17, 2014

World Bank (2012a) In Search of Opportunities: How a More Mobile Workforce Can Propel Ukraine's Prosperity (Vol. 1 and 2). World Bank, Washington, DC

World Bank (2012b) World Development Report 2013: Jobs. World Bank, Washington, DC

doi:10.1186/s40175-014-0021-3

Cite this article as: Koettl et al: In search of opportunities? The barriers to more efficient internal labor mobility in Ukraine. IZA Journal of Labor \& Development 2014 3:21. 